\title{
Dreams and needs: The applications of isotopes to industry in Spain in the 1960s
}

\author{
Francesc X. Barca-Salom \\ Universitat Politècnica de Catalunya. \\ crht@etseib.upc.es
}

Dynamis

[0211-9536] 2009; 29: 307-336
Fecha de recepción: 22 de febrero de 2008

Fecha de aceptación: 13 de junio de 2008

SUMMARY: 1.-Introduction. 2.-Dreams. 3.-Advantages of collaboration. 4.-Courses on isotopes applied to industry imparted by the JEN. 5.-Early activities of the Section of Isotopes of the JEN. 6.-Promotion of needs. 7.-The food industry. 8.-The era of tracers. 9.-Exempted products. 10.-Culmination of the phase. 11.-Conclusion.

ABSTRACT: The efforts to change the bleak image of the atom bomb galvanised the discourse on the peaceful applications of nuclear energy. This contributed to a utopian vision of nuclear energy, especially of the uses of radioactive isotopes in the immediate post-war period. Desire for peace engendered dreams of a better future based on the use of radioactivity. These dreams were first converted into reality using isotopes in medicine. These advances were subsequently applied to industry and agriculture. This article gives an overview of the peaceful applications of isotopes in industry and agriculture in Spain. It describes a period in which the initial dreams, sometimes fantastic and other times down-to-earth, gave rise to the first applications to meet the needs of economic growth in the 1960s.

PALABRAS CLAVE: Isótopos, industria, agricultura, energía atómica, España.

KEY WORDS: Isotopes, industry, agriculture, atomic energy, Spain.

\section{Introduction}

The dropping of the atom bombs in Hiroshima and Nagasaki, which hastened the end of World War II, brought about great consternation in the world because of its awesome destructive power. After the War, the victorious nations endeavoured to change the image of atomic energy by highlighting its peaceful uses. These efforts were rewarded after the Atoms for Peace program promoted by the USA, which enabled friendly 
countries to gain access to information and receive economic help to construct reactors for research.

There were two peaceful applications of nuclear energy following WW II: nuclear power to generate electricity and the application of isotopes to medicine ${ }^{1}$, food and industry.

In the post-war period, the dearth of information in many countries without nuclear energy such as Spain gave rise to an idyllic image of these applications not only in the public mind but also among scientists albeit to a smaller degree. This paper describes the image created by some scientific journals in the promotion of the desire of peaceful uses of nuclear energy. However, the situation changed with the passage of time. The creation of research centres, special training centres and reactors for research encouraged development and transformed these initial dreams into a policy that promoted needs.

An attempt is made to trace the development of isotopes for industrial applications in Spain from the creation of the Nuclear Energy Board (Junta de Energía Nuclear or JEN) until the end of the decade of 1960-1970. In this period the applications of isotopes to the productive processes in industry and agriculture underwent a considerable increase due mainly to the activities of the JEN and to the needs created by economic growth. An overview of the development of isotope applications to industry through the activities of the JEN is presented. Our approach is based on the information obtained from articles in technical journals and reports, and it is hoped that it will provide an incentive for further research to complement the study.

\section{Dreams}

The first information on isotopes reached Spain via technical journals from the industrialized countries. In Spain, whose population had lived in isolation in an autarchy imposed by the Franco dictatorship, the news of the

1. The applications of isotopes in medicine and biology in Spain were studied in Santesmases, Maria Jesús. Peace propaganda and biomedical experimentation: Influential uses of radioisotopes in Endocrinology and Molecular Genetics in Spain (1947-1971). Journal of the History of Biology. 2006; 39: 765-796. A comparative perspective between US, England, France and Spain is included in Creager, Angela. N. H. Radiobiology in the atomic age: Changing research practices and policies in comparative perspective. Journal of the History of Biology. 2006; 39: 637-647. 
significant advantages of isotopes in medicine and agriculture was received with something akin to awe. However, the uses of isotopes in industry were less known although they were appreciated by those industrialists who realised their potential for business.

The image created around the peaceful uses of atomic energy was full of optimism. This, however, was not spontaneous; but sprang from the desire to replace the bleak image of the atom bomb by the argument that peaceful uses of atomic energy could benefit mankind. The first uses considered were isotopes in medicine although greater emphasis was being simultaneously laid on the production of cheap electricity to ease the shortage in some countries in the post-war period. However, the application of isotopes to industry encountered a major obstacle. The purchase of the necessary equipment could not be offset by the economic benefit derived from its use, which delayed its application. Joaquín Catalá professor of Physics of the University of Valencia summed up the 1947 situation in the following words: «In any case when calculating the commercial value of these radioactive substances (isotopes), obtained from the pile, it may be concluded that at the present time the cost of its production and use cannot be offset, which means that it is not feasible to purchase these products and make a living from them» ${ }^{2}$.

Nevertheless some journals for scientists and technicians continued to present an excessively optimistic image of the applications of isotopes to industry. Thus the publicist José Barceló in an effort to highlight the advantages of isotopes proclaimed that special radioactive sand had been developed in the USA, which killed insects that were harmful to crops. Articles in foreign journals claimed that it would not be long before isotopes were applied to the metallurgic industry to eliminate the impurities from alloys ${ }^{3}$.

However, those responsible for the applications of atomic energy in Spain continued to be optimistic albeit more cautious. Thus, José Miguel Gamboa, director of the section of isotopes of the JEN affirmed in 1952 that the applications of isotopes in industry were almost as important as

2. Catalá, Joaquín. La energía atómica en la industria. Ion. 1947; 7: 669-761, 764-767, 829-833.

3. Hubert Plant, C. La metalurgia y la energía atómica. Acero y Energía. 1948; Jul-Aug: 318-322. Aplicaciones industriales de la energía nuclear. Physicalia. Boletín de la Asociación Nacional de Físicos de España (ANFE). 1950; 2 (3): 19-22. 
the production of electricity and that in the future we would see which of the two applications was more profitable 4 .

This idea of educating the scientific and technical community as well as the general public was not a phenomenon peculiar to Spain but formed part of a pre-conceived strategy on the part of the US government as John Krige writes: «The education of desire for the peaceful atom was not achieved by diffusion, but by a deliberate policies of the hegemonic authority, the United States in this case, policy which subverted the openness of the utopian project and restricted the agency of those who were embarking along it» 5 .

Applications of isotopes were not entirely unknown in Spain. Since the start of the XX Century natural isotopes had been used at the Instituto de Radiactividad (Radioactivity Institute). This centre was set up by José Muñoz del Castillo, professor of chemical mechanics and inorganic chemistry at the University of Madrid, in 1903 in order to carry out research into noble gases and to measure radiation. However, this Institute declined after 1920 and was annexed to the Instituto Nacional de Geof ísica del CSIC (the National Institute of Geophysics of the High Council of Scientific Research) in $1940^{6}$.

The first references to nuclear energy appear in Spain in scientific reports, e.g. in the journal Ibérica ${ }^{7}$ and in a lecture delivered by the Jesuit teacher Ignacio Martin Artajo at the ICAI (Catholic Institute of Arts and Industries) in $1945^{8}$. Nevertheless, the preliminary steps were taken in the field of mining given that the government had reserved all the uranium deposits for the State. Spain possessed considerable deposits of uranium. Thus, in October 1945 the Minister of Industry laid claim to the uranium

4. Gamboa Loyarte, José Miguel. Las investigaciones nucleares y sus repercusiones [Lección inaugural del curso 1952-1953]. Universidad de la Laguna.

5. Krige, John. Techno-utopian dreams, techno-political Realities. The education of desire for the peaceful atom [Unpublished paper]; 2008.

6. Herran, Néstor. Aguas, semillas y radiaciones. El Laboratorio de Radiactividad de la Universidad de Madrid, 1904-1926. Madrid: CSIC; 2008.

7. Maldonado, Francisco. La bomba atómica. Ibérica. 1945; 32: 180-182,188.

8. The title of the lecture was: Energía atómica. Sus características y aplicaciones para fines militares. See Ordoñez Javier; Sánchez Ron, José M. Nuclear energy in Spain. From Hiroshima to the sixties. In: Forman, Paul; Sánchez Ron José M. National military establishments and the advancement of science and technology. Boston: Kluwer Academic Publishers; 1996, p. 185-213. 
deposits of fourteen provinces ${ }^{9}$. Some months before the Geological and Mining Institute had set up a commission to study the deposits of uranium in Spain, and at the end of 1945 they organised a cycle of lectures on this subject with the collaboration of the Association of mining engineers. One of these concerned the discovery of an important deposit of uranium by A. Carbonell in the Sierra de Albarrana (Cordoba) in $1936^{10}$.

Mining also played a crucial role in the Spanish nuclear research project. In April 1948 Francesco Scandone, from the University of Florence, delivered a lecture at the CSIC (Council for Scientific Research) in Madrid ${ }^{11}$. During the break, Scandone enquired about uranium deposits in Spain. Armando Duran, professor of physics, who had attended the lecture, introduced Scandone to General Juan Vigon. This meeting led to a secret collaboration on nuclear training between Italy and Spain.

In September 1948 Franco passed a secret law setting up the Atomic Research Board (Junta de Investigaciones Atómicas). This Board, which consisted of José Maria Otero Navascués, Manuel Lora Tamayo, Armando Durán Miranda and José Ramon Sobredo Rioboo, took on the outward appearance of a company known as Estudios y Patentes de Aleaciones Especiales (EPALE) under the supervision of the eminent scientist Esteve Terradas.

The EPALE initially sent scientists abroad for training. First, Ramon Ortiz Fornaguera went to Milan, and then Carlos Sánchez del Rio and Maria Aranzazu Vigon travelled to Rome and to Milan. At the same time José M. Otero Navascués visited professor Scherrer at the Polytechnic of Zurich, and met professors Heisenberg and Karl Wirtz at the Max Planck Institute in Gottingen. He also made contact with Samuel K. Allison at the University of Chicago, professors Bolla and Amaldi at the Polytechnic Institute in Milan and with other distinguished scientists from Belgium,

9. Decree October 4th, 1945. Boletín Oficial del Estado (BOE); no 278: p. 2133.

10. Memorias del Instituto Geológico y Minero de España. Uranio. Curso de Conferencias. Madrid: Tip-Lit. Coullant; 1946.

11. Francesco Scandone was director of the Galileo House in Milan, which made scientific instruments for optics, and was a member of the board of the CISE (Centro di Informazioni, Studii ed Esperience). Romero de Pablos, Ana.; Sánchez Ron, José M. Energia Nuclear en España. De la JEN al CIEMAT. Madrid: CIEMAT; 2001, p. 15. The authors consider that Scandone came to Spain under the pretext of dealing with some aspects of optics but in fact he contacted the Spanish authorities with a view to establishing collaboration between Spain and Italy in nuclear energy. 
France, and Britain. Some of these scientists were invited to Madrid to give courses or lectures ${ }^{12}$.

The activities of the first period (1948-1951) were shrouded in secrecy. In 1950, following the death of Esteve Terradas, General Vigon became the new director of the EPALE. This marked the beginning of a new and crucial period during which secrecy gave way to discretion.

The Spanish Nuclear Agency (Junta de Energía Nuclear, JEN) was set up in 1951. The JEN was conceived with grandiose designs. It sought to establish full control over all the fields related to nuclear energy: mining, training, research, radioactive protection, advice on nuclear matters, and the production and sale of isotopes. As regards isotopes, the JEN was responsible for nuclear medicine and radioactive protection and for the manufacture and distribution of isotopes in their different applications in medicine, industry or agriculture ${ }^{13}$.

Artificial isotopes were first employed, in gammagraphy, in Spain in 1950 just before the creation of the JEN. In early 1950, the company ENCASO (Empresa Nacional Calvo Sotelo) requested the Instituto de la Soldadura (Soldering Institute) for some help to carry out radiography surveys in the soldering of boiler pipes at the thermal power station under construction at Puertollano. However, this Institute underestimated the magnitude of this task and was obliged to offer the work to Solus Schall Ltd, an English company, which subsequently shipped staff and equipment (one transmitter of gamma rays with an Iridium 192 source) to Spain ${ }^{14}$. On the completion of the survey, the equipment was acquired by the Soldering Institute, which used it to set up a service of industrial gammagraphy. In late 1954, a research worker from the Institute was sent to the Isotope School at Harwell for training. The Institute purchased three new instruments of Iridium 192 in 1955 and another one of Cobalt 60 in $1957^{15}$.

Meanwhile, in 1951 the JEN was set up with the following aims: to produce and distribute isotopes to the medical, industrial and agricultural sectors, and to provide protection against radiation ${ }^{16}$.

12. Three trips made by Otero Navascués in 1949, 1950 and 1951 have been recently documented. Romero; Sánchez Ron, n. 11, p. 30-40.

13. Law October 22, 1951. BOE. 24 Oct., 1951: 4778-4779.

14. Domínguez Rodríguez, Germán. Isótopos. Energía Nuclear. 1976; 20, 103: 407-419.

15. Ruiz Rubio, Angel. La gammagrafía, su estado actual y posibilidades futuras. Energía Nuclear. 1967; 48: 309-318

16. Decree October 22, 195. BOE. 24 Oct., 1951: 4778-4779. 
In the period 1951-1955 the activity of the JEN was supervised by General Vigon and was characterised by impressive projects such as the building of a large research centre and a facility for uranium treatment. Nevertheless, these ambitious projects ran into difficulties because of the isolation of Spain and the secrecy surrounding the activities of the nuclear powers.

The project of the research centre was conceived at the same time as the creation of the JEN and was advised by the German scientist Karl Wirtz, who travelled to Madrid to discuss the details. General Vigon wished to build a large centre in accordance with the ambitious objectives of the JEN but Wirtz was more pragmatic and recommended the creation of universities for the training of future scientists and technicians ${ }^{17}$.

The construction of the uranium treatment plant at Andújar, the other achievement of the JEN in this period, began in 1956. This village in Jaén was chosen because of its location midway between the uranium mines: Cardeña in Córdoba and Virgen de la Cabeza in Jaén. This construction benefited from the considerable experience gained at the chemical laboratory of the University of Madrid and at the new pilot plant at the Centre of Nuclear Studies in Madrid ${ }^{18}$.

\section{Advantages of collaboration}

In 1953 President Eisenhower proposed the Atoms for Peace Programme with the aim of controlling the nuclear activities of other countries in exchange for help in developing nuclear energy for peaceful purposes ${ }^{19}$. To this end, an international conference was held in Geneva in 1955. This conference was attended by delegates from more than seventy countries including Spain. Among the subjects discussed were the applications of Carbon 14 for dating objects and Cobalt 60 for treating disease in place

17. Presas Puig, Albert. La correspondencia entre José M. Otero Navascués y Karl Wirtz un episodio de las relaciones internacionales de la Junta de Energía Nuclear. Arbor. 2000; 659-660: $527-$ 601.

18. Requena, Eduardo. La Junta de Energía Nuclear. XXV aniversario. Madrid: Junta de Energía Nuclear; 1976, p. 68.

19. Parsons R.M. History of technology policy-commercial nuclear power. Journal of Professional issues in Engineering Education and Practice. 1995; 121 (2): 85-98; Hewlett, Richard G. Atoms for peace and war 1953-1961. Berkeley: University of California Press; 1989, p. 209-271. 
of Radium. More than six hundred hospitals and laboratories in forty six countries received isotopes from the Atomic Energy Commission. This number indicates the widespread use of isotopes in the world ${ }^{20}$.

However, at that time, the main subject of nuclear applications was the generation of electricity. Consequently, the JEN reached an agreement with the USA whereby Spain received the Uranium necessary for a research reactor (purchased from General Electric and inaugurated in 1958). This paved the way for the JEN to construct a new research centre at Moncloa near Madrid.

Another result of the First Conference was the creation of a chair of nuclear engineering - The Ferran Tallada Chair. On the initiative of Joaquin Ortega Costa, the Industrial Engineering School of Barcelona inaugurated the Ferran Tallada Chair for nuclear engineering after the First International Conference at Geneva in 1955. As in the case of other chairs, the name of a prominent engineer was chosen ${ }^{21}$.

The time of the creation of this special chair was opportune given that at the beginning of 1955 the General Direction of Technical Education had begun to study the reform of Engineering Studies in order to adapt them to modern technologies. The syllabus applicable at that moment was the one of 1948, which was very inflexible and uniform and did not allow the addition of any new specialities to the existing ones of: Mechanics, Electricity, Chemistry, and Textiles.

The teaching activity of the Ferran Tallada Chair also included isotopes. Nevertheless, the first course started modestly with only two teachers and a short syllabus: an introduction to nuclear engineering and an elementary theory of reactors ${ }^{22}$. In 1957 the Ferran Tallada Chair organised three

20. Átomos para la paz. Los resultados de la Conferencia de Ginebra. Metalurgia y Electricidad. 1956; 220: 150-153

21. Ferran Tallada Cumella (1881-1937) had previously occupied the chair of integral calculus and rational mechanics at the Engineering School. In 1932 Tallada obtained a grant to go to Paris to study physics and quantum mechanics with León Brillouin, Louis de Broglie and Eugene Bloch. The following year he joined the Maurice de Broglie laboratory near Paris, but he fell ill and was obliged to return to Barcelona, where he died in 1937. Roca Rosell, Antoni. Los científicos catalanes pensionados por la Junta. In: Sánchez Ron, José M., coord. 1907-1987. La Junta para Ampliación de Estudios e Investigaciones Científicas 80 años después. Simposio Internacional. Madrid 15-17 Diciembre 1987. Madrid: Consejo Superior de Investigaciones Científicas; 1988, p. 349-379.

22. Programa para el curso 1955-56. Cátedra Fernando Tallada. Barcelona: Escuela Especial de Ingenieros Industriales; Oct 1955. 
courses with the collaboration of foreign teachers. The first course was supervised by scientists from the JEN, the second, directed by Thomas Reis from the French École Normal Superieur du Pétrole, and the third course was given by Leon Jacques from the École Polytechnique in Paris and dealt with isotopes The first session was devoted to explaining the difference between natural and artificial isotopes, and to production and separation. The second concerned the applications of the isotopes in the industry, metallurgy, chemistry and mechanics. And the third course focused on the applications of isotopes to biochemistry and on safety measures ${ }^{23}$. The following year these topics were incorporated into the regular course.

The implementation of isotopes to industry in Spain was not only due to the First Congress of Geneva but also to the creation of some schools of isotopes at Harwell (Great Britain) and at Saclay (France), where some of the teachers of the Ferran Tallada Chair received their training. Other influences were the development of these techniques in Europe and their diffusion and circulation in the late $1950 \mathrm{~s}^{24}$.

The year 1957 marked a turning point given that the courses imparted in Madrid concerned the application of isotopes exclusively to science and medicine. ${ }^{25}$ The JEN set up the Section of Isotopes to supply and promote the use of isotopes and also to train users. This Section was initially housed in the Instituto Nacional de Oncología (National Institute of Oncology) and the first measure it took was to authorize those persons or institutions that had used isotopes previously. Twenty seven authorizations were conceded but none were granted for industrial applications ${ }^{26}$. The

23. Ciclo de conferencias sobre isótopos. Cátedra Fernando Tallada. Barcelona: Escuela Especial de Ingenieros Industriales; Mar 1957. The title of lectures was: 1) Isotopes naturels et artificiels. Moyens de production et de séparation. 2) Applications des isotopes naturels. Applications des radio isotopes aux industries métallurgiques, chimiques, mécaniques. 3) Emplois biochimiques des radio isotopes. Applications dans la recherche des laboratoires. Précautions d'emploi.

24. Herran, Néstor. Spreading nucleonics: the Isotope school at the atomic energy research establishment 1951-67. BJHS. 2006; 39 (4): 569-586.

25. Barca-Salom, Francesc X., Els inicis de l'Enginyeria nuclear a Barcelona. La Càtedra Ferran Tallada (1955-1962) [PhD dissertation]. Barcelona: Universitat Politècnica de Catalunya, 2002. See: http/www.tdx.cbuc.es/. Barca-Salom, Francesc X. Nuclear power for Catalunya: The role of the official chamber of Industry of Barcelona (1953-1962). Minerva, 2005; 43 (2): 163-181. Barca-Salom, Francesc X. Aplicacions dels isòtops a la indústria durant el franquisme. Quaderns d'Història de l'Enginyeria. 2005; 7: 1-44.

26. Gamboa Loyarte, J.M.; Del Val Cob, M. El Centro Nacional de Energía Nuclear «Juan Vigón»: La Sección de Isótopos. Energía Nuclear. 1960; 15: 5-19. 
Section also began to supply isotopes purchased from abroad since local production was inexistent.

When the JEN-1 reactor became critical in 1958, there were new possibilities for the Section of Isotopes to commence production and hence reduce foreign imports ${ }^{27}$. Phosphorous 32 and Sulphur 35 were the first isotopes to be produced in Spain for application in medicine, calibration and gammagraphy. In late 1959 the JEN authorized 63 isotope installations, three of which belonged to industry. These three installations were located in Madrid and were probably the aforementioned instruments of the Soldering Institute 28 .

\section{Courses on isotopes applied to industry imparted by the JEN}

The initiative to impart courses on the industrial applications of isotopes had its origin in the Barcelona Special School of Industrial Engineering. This led to the implementation of courses on this subject in the JEN. The aim of these courses was to enable persons wishing to manipulate isotopes to obtain a diploma in accordance with the regulations of JEN which stated: «The persons, entities, centres and institutions wishing to use radioactive isotopes in the national territory must acquire the condition of User of the Section of Isotopes of the Board of Nuclear Energy by making a request to the Excmo. President of this organism and in a form whose official model will be facilitated for the Section of Isotopes to all those wishing to be a User» ${ }^{29}$.

The events unfolded as follows: in January 1959, Damian Aragonés, director of the Escuela Técnica Superior de Ingenieros Industriales (Technical School of Industrial Engineering) of Barcelona ${ }^{30}$ invited J.M. Gamboa Loyarte from the Section of Isotopes to Barcelona. This visit took place in

27. Domínguez Rodríguez, Germán; Del Val Cob, Manuel. Utilización del reactor JEN-1 para la producción de isótopos radiactivos. Energía Nuclear. 1963; 28: 43-59.

28. Gamboa, J.M.; Ramos, E.; Del Val Cob, M.; Martínez, J.M. Legislación y reglamentación del uso de radioisotopes. Energía Nuclear. 1964; 29: 45-87.

29. Instructions to the applicants for the certificate of user of the Section Of Isotopes of the. Board of Nuclear Energy. Section of Isotopes. Circular: ISA -2. Ferran Tallada Boxes. Archive of the Technical School of Industrial Engineering of Barcelona.

30. The Special School of Industrial Engineering at Barcelona was designated as the Technical School of Industrial Engineering of Barcelona due to new technical education law of 1957. 
June and Aragonés took advantage of the occasion to let him know of his intention to build a nuclear reactor for the Ferran Tallada Chair - he was referring to the Argos, the construction of which had already begun in Madrid - and of the need for technicians trained in the use of isotopes ${ }^{31}$. Aragonés presented a plan to implement courses in the first three months of the following academic course. This proposition was implemented in February 1960 when the JEN organised the first course on the applications of isotopes to industry and the second, at the end of April. In the short period of fifteen days they managed to train teachers and industrialists to be users of isotopes ${ }^{32}$. Despite the difficulties encountered in the preparation of the laboratory, the following course, the third, was held in March 1961 in Barcelona and was inaugurated by Donald A. Fayres, director of the Isotope School at Wantage in Great Britain. Ramon Simon, one of the holders of the Ferran Tallada Chair, imparted classes on theory. Technicians from the most important companies such as Materiales y Construcciones, Fecsa, Macmor and Cros attended the course as pupils. The following course, the fourth, was also held in Barcelona and was not attended by technicians but by students. The reason for this was the lack of laboratory equipment and the fact that no certificate was awarded at the end of the course ${ }^{33}$.

The desire to impart this course in Barcelona was thwarted and it was necessary to wait for two more years. On the initiative of the Spanish Atomic Forum, the first meeting on isotopes took place in Barcelona in 1964, which rekindled an interest in these courses.

The Spanish Atomic Forum was created in 1962 by electricity companies with the aim of exchanging ideas and information on nuclear issue and participating on equal terms with the other European countries in the European organization FORATOM. The intention to participate in the organization of the meeting of isotopes in Barcelona was one of the activities of the Forum. However, Damià Aragonés, the director of the School of Industrial Engineering of Barcelona, was replaced by José M. de Orbaneja, which led to a delay in the preparatory activities of the meeting.

31. Minutes 22 and 23. Ferran Tallada Boxes. Archive of the Technical School of Industrial Engineering of Barcelona.

32. Personal Archive of Ramon Simon Arias. Grateful thanks are extended to his daughter Dra. Julia Simon Arias for facilitating access to the archive.

33. Minute 27. Ferran Tallada Boxes. Archive of the Technical School of Industrial Engineering of Barcelona. 
It was the intention of the Forum that this meeting should resemble those organised in Paris by the ATEN (Association Technique pour la production et utilisation de l'Energie Nucleaire) - an entity composed of some sixteen private societies- and that it should make an impact not only on industry in Barcelona but also in Catalonia and in other parts of Spain ${ }^{34}$.

The definitive program of the meeting was completed in December of 1963 and the organizing committee was constituted by Germán Domínguez Rodríguez, of the Section of Isotopes Use of the JEN, José Ramón Galvan Cabrerizo, of the INI, Manuel Golmayo of the company AUXINI, and José Javier Clua, of the School of Barcelona. In the same month Gaztelu and De Melis travelled to Barcelona to establish contacts with the Official Chamber of Industry, the Medical Association, the Faculty of Medicine, the Provincial Regional Government and the Town Council. Most of the expenses were borne by entities from Barcelona and were destined for one exhibition, design by R. Terradas the architect. The meeting was held from 9 to 15 March and consisted of a series of lectures delivered mostly by teachers of the JEN or the ministries. Antonio Subias was the only lecturer from Barcelona. The exhibition displayed a number of devices of gammagraphy, measures of levels and thicknesses and other applications in industry and some films were also projected.

Two years later, the JEN agreed to organise the XIII course on the application of radioisotopes to industry at the Engineering School of Barcelona with the support of the Official Chamber of Industry ${ }^{35}$. Courses V to XII were given in Madrid from 1962 to 1965, at the rate of two every year. So, in 1964 the IX and X courses on applications of radioisotopes to industry were held in the JEN.

\section{Early activities of the Section of Isotopes of the JEN}

After two years in the National Institute of Oncology, the Section of Isotopes, which formed part of the Division of Chemistry, was moved to the building housing Medicine, Protection and Isotopes at the Research Centre

34. From Melis to Orbaneja. Madrid, November, 26, 1963. Ferran Tallada Boxes. Archive of the Technical School of Industrial Engineering of Barcelona.

35. XIII Curso de Aplicaciones de los Radioisótopos en la Industria. 1966. Barcelona from January 24 to February 19. 
of Nuclear Energy at Moncloa (Madrid). The Section of Isotopes occupied half the basement and half of the second floor. The laboratories of gamma and beta transmitters were assigned to the basement, and the second floor was destined for students.

The Section was divided into six departments: 1) Distribution and general control, 2) Synthesis, 3) Research into physics and chemistry, 4) Industrial applications, 5) Animal biology and medical applications, and finally, 6) Plant biology and agricultural applications.

The department of Distribution and general control was responsible for dispatching orders not only for isotopes produced by the JEN - Iodine 131 and Phosphorus 32- but also for the ones imported from other countries. The department of Synthesis was dedicated to the supply of marked compounds such as baric carbonate marked with Carbon 14 given that these products were expensive, accounting for a considerable amount of foreign currency.

The department of Applications of animal biology and medicine was the most advanced because marked molecules destined for medicine had been synthesized, which meant that the isotopes produced were to be applied in medicine. These isotopes consisted of molecules marked with Iodine 131 to study fat metabolism, kidney function, and to detect tumours. Gamma globulins and vitamins marked for the study of the anaemia were also synthesised.

The department of Plant biology and agriculture and the department of Research on physics and chemistry were in the preliminary stages. Thus, in Plant biology the production of starch and glucose was marked with Carbon 14 for the biosynthesis of tobacco leaves and some experiments of Phosphorus 32 absorption were made in plants. Moreover, super phosphates marked with this isotope were synthesised.

The department of Industrial applications focused more on its future contribution to the national economy than to research activity. One of its main activities was the organisation of two courses of Isotopes in the School of Industrial Engineering in Barcelona in 1960 and $1961^{36}$. Although the Section of Isotopes had made an effort to promote these new techniques through courses, lectures and reports, certain entrepreneurs were reluctant to apply them because of their conservative attitudes. Only ten researchers 
including José Miguel Gamboa Loyarte, Manuel Val Cob and Manuel Martínez were in charge of the Section of Isotopes.

Isotopes were available to anybody who requested them by mail, telephone or telegram. The interested persons placed their order by telex and the Section confirmed it by letter. The majority of the isotopes were obtained from the Radiochemical Centres at Amersham and Harwell in Great Britain, Phylips Duphar in Holland and Tracerlab in the USA. The Section of Isotopes at the beginning of the 1960s had a stock of Iodine 131, Phosphorus 32 and Sulphur 32 that were the most requested isotopes owing to their applications in medicine. However, the isotopes for industry were still scarce.

Moreover, the Division of Chemistry of the JEN, in the two years of operation of the reactor JEN-1, succeeded in elaborating a few remittances of phosphorus 32 and sulphur 35.

The Section of Radiochemistry, which also depended on the Division of Chemistry, was also created. This section was charged with studying the products of fission from the reactor JEN-1 to carry out the production of radioisotopes. Thus, while the Division of Chemistry was responsible for producing some isotopes, the Section of Isotopes distributed them and the Section of Radiochemistry obtained new isotopes from the reactor: Phosphorus 32, Sulphur-35, Gold 198, Chromium 51 and Iodine $131^{37}$. This Section had eight technicians including German Dominguez and twelve assistants and was divided into six departments: Production and development, Products of fission, Marked compounds, Analysis by activation, Metrology and Mechanical constructions ${ }^{38}$.

Of the early research carried out by these Sections, the study of the mechanism of transposition of the alkyl group in the $\mathrm{N}$-alkylanilines using Carbon 14 as a tracer and the extension of N-N-propylaniline should be noted ${ }^{39}$.

Another work concerns the implementation of a method to obtain Phosphorus 32 by distillation of irradiated Sulphur in a flow of fast neutrons. The isotope of Phosphorus was produced inside the mass of Sulphur by the replace-

37. Domínguez, n. 27, p. 50.

38. Producción y consumo de isótopos radiactivos en España en 1964. Energía Nuclear. 1965; 37: 377-389.

39. Molera, M. J.; Gamboa, J.M.; Del Val Cob, M. Estudio de la transposición de N-Alquilanilinas a P-Aminoalquilbenceno mediante ${ }^{14} \mathrm{C}$ III N-n-Propilanilina. Madrid: Junta de Energía Nuclear; 1961. Published also In Anales de la Real Sociedad de Física y Química. 1959; 55 (6): 493. 
ment of a proton by a neutron. This method was tested in the laboratories of the JEN in early 1961 and proved so simple that the isotope became routinely produced by the auxiliary staff ${ }^{40}$.

In general, the methods developed in the JEN were applications of the methods from other research centres in Europe or America, where Spanish researchers had received their training. This does not rule out the possibility of new contributions to these applications in Spain with the result that a method could be patented in the General Registry of Patents.

In the early 1960s a radioactive isotope was used in Spain to locate water leaks. These leaks occurred in the Division of Chemistry of the National Centre of Nuclear Energy in Madrid. The basement of these buildings had suffered from humidity. Bromine 82 was used as a tracer to detect the origin of the leak. Two leaks were detected, a big one and small one, accounting for the humidity ${ }^{41}$. However, there is no evidence to support the belief that this method was subsequently used to detect humidity in buildings on a large scale.

There was an increase in the initial applications in the following years as shown in Table 1, in which we can see that the industrial applications come after medicine.

Table 1: Number of users of isotopes between 1957 and 1962

\begin{tabular}{lccccc}
\hline \multirow{2}{*}{ Field of application } & \multicolumn{5}{c}{ Years } \\
\cline { 2 - 6 } & 1957 & 1958 & 1959 & 1960 & 1961 \\
\hline Research into physics and chemistry & 5 & 5 & 6 & 9 & 12 \\
Industry & - & 2 & 3 & 7 & \\
Vegetable biology and agriculture & - & 1 & 2 & 2 & 2 \\
Animal biology and medicine & 16 & 31 & 33 & 43 & 61 \\
Total users & 21 & 39 & 44 & 67 & 89 \\
\hline
\end{tabular}

Source: Domínguez; Del Val, n. 26, p. 54.

40. De la Cruz, Felipe; Suárez, Cristina; Domínguez, Germán. El Centro Nacional de Energía Nuclear «Juan Vigón»: Preparación de Fósforo-32 por destilación de Azufre Irradiado. Energía Nuclear. 1962; 22: 4-15.

41. Gamboa Loyarte, J.M.; Del Val Cob, M.; Plata Bedmar, A.; Noreña de la Cámara, S. Utilización de Isótopos Radiactivos en problemas de construcción. Energía Nuclear. 1961; 17: 57-63. 
The JEN realised that the situation was favourable in the medical sector and that it was necessary to implement these techniques in industry ${ }^{42}$.

The increase was progressive and was related to the construction of research reactors such us those of JEN, the ARBI and the Argos. The steady development of industry, the confidence in the applications of isotopes and the number of trained users of isotopes accounted for the surprising growth of applications in industry from 1962 onwards.

\section{Promotion of needs}

The applications of radioactive isotopes to industry underwent a sharp increase after 1963. Gammagraphy, which was the first application in this field, was restricted to a single centre in 1957. In 1967, forty five installations were in operation with Iridium 192, which had been produced by the JEN since $1963^{43}$.

Another application, which experienced a sharp rise during this decade, was the instruments of industrial control equipped with isotopes. These instruments constituted a radioactive test consisting of a small activity source, a detector and an electronic device to convert the signal into a digital or analogical one.

This equipment was designed to measure physical properties such as thickness of materials, levels of liquids, density or humidity. In all these cases, rays were beamed across the material and alterations were detected by the variations in the flux.

From 1963 to 1967 there was a threefold increase in the number of instruments of industrial control. Table 2 gives the distribution of these instruments in accordance with the different industries. The chemical sector emerged as the main user of these instruments with the result that installations increased from 14 to 40 . The paper and wood, and the construction sectors showed a similar rise. However, there were no applications in the food, textile, cement and machinery sectors.

In 1961, Spain was lagging behind the 23 pioneering countries that used nucleonic equipment of control. This could be due to the fact that

42. Domínguez, n. 27, p. 53.

43. Ruiz, n. 15, p. 312 
the industrial structure was deficient and to the fact that the radioisotope techniques were not sufficiently widespread. But the end of the decade marked a radical change. In 1963 the JEN had authorized 18 facilities of this type, whilst in 1967 the number had trebled. Thus, this resulted in a considerable development and implementation of these techniques in industry. Table 3 shows the distribution of the facilities of industrial control according to the type of industry where they were applied and according to the type application to which they were destined. Overall, all these innovations represented a profit of 98 millions of PTA. (589.000 €) in 1967 - similar to that of Austria or Portugal but amounting to less than 1\% of the USA profits ${ }^{44}$.

Most users were located in Catalonia and the Basque country (Manhusa, Coromina Industrial S.A., and Glucosa y derivados S.A. from Barcelona, J. Boncompte i la Forestal d'Urgell from Lleida or the Compañia Española de Plásticos S.A. and ICOA S.A. from Basauri, Vizcaya).

Table 2: Number of nucleonic instruments in relation to industries.

From 1963 to June 1967

\begin{tabular}{|c|c|c|c|c|c|c|c|c|c|c|c|c|}
\hline \multirow[t]{3}{*}{ Industries } & \multicolumn{6}{|c|}{1963} & \multicolumn{6}{|c|}{1967} \\
\hline & \multirow{2}{*}{$\begin{array}{c}\text { Installations } \\
\text { authorized }\end{array}$} & \multicolumn{4}{|c|}{ No. Instruments } & \multirow[t]{2}{*}{ Total } & \multirow{2}{*}{$\begin{array}{c}\text { Installations } \\
\text { authorized }\end{array}$} & \multicolumn{4}{|c|}{ No. Instruments } & \multirow[t]{2}{*}{ Total } \\
\hline & & $E$ & $D$ & $N$ & $V$ & & & $E$ & $D$ & $N$ & V & \\
\hline Tobacco & 1 & & 2 & & & 2 & 1 & & 2 & & & 2 \\
\hline Wood and paper & 2 & 4 & & & & 4 & 10 & 12 & & & & 12 \\
\hline Rubber & 1 & 6 & & & & 6 & 2 & 7 & & & & 7 \\
\hline Chemistry and & 5 & 12 & & 2 & & 14 & 17 & 21 & 6 & 13 & & 40 \\
\hline \multicolumn{13}{|l|}{ Plastics } \\
\hline Petrol and coal & & & & & & & 2 & & & 4 & 1 & 5 \\
\hline Basic metals & 7 & 12 & & & & 12 & 13 & 14 & & 4 & & 18 \\
\hline Construction & 1 & & 2 & & & 2 & 6 & & 14 & & & 14 \\
\hline Others & 1 & & & & 1 & 1 & 4 & & & 2 & 1 & 3 \\
\hline TOTAL & 18 & 34 & 4 & 2 & 1 & 41 & 55 & 54 & 22 & 23 & 2 & 101 \\
\hline
\end{tabular}

$\mathrm{E}=$ thickness, $\mathrm{D}=$ density, $\mathrm{N}=$ level, $\mathrm{V}=$ others ( $\mathrm{p}$. ex. analysis)

Souce: Del Val, n. 44, p. 330. 
One area in which the Section of Isotopes of the JEN had a direct participation was the construction of the building for Critical Experiments at the National Centre of Nuclear Energy in Madrid. Isotopes were incorporated in tools to measure ground density. To this end, the JEN designed and patented some tools: one in the form of a $U$, another in the form of a cross and another for backscattering.

This patent was one of the forty that the JEN obtained between 1955 and 1966. As can be seen in the Graphic 1, the distribution of patents reached a maximum in 1957 and a minimum in 1961. The average was about four patents a year. Most of the patents corresponded to improvements in the procedures of preparation of elements such as Iodine 131, radioactive sulphites, carbides of uranium and phosphor 32. The General Spanish Registration of Patents contains a «Device for the measure of the density of grounds by transmission of the gamma radiation " of the year 1963 corresponding to the aforementioned instruments.

Graphic 1. Distribution of the number of patents (1955-1966)

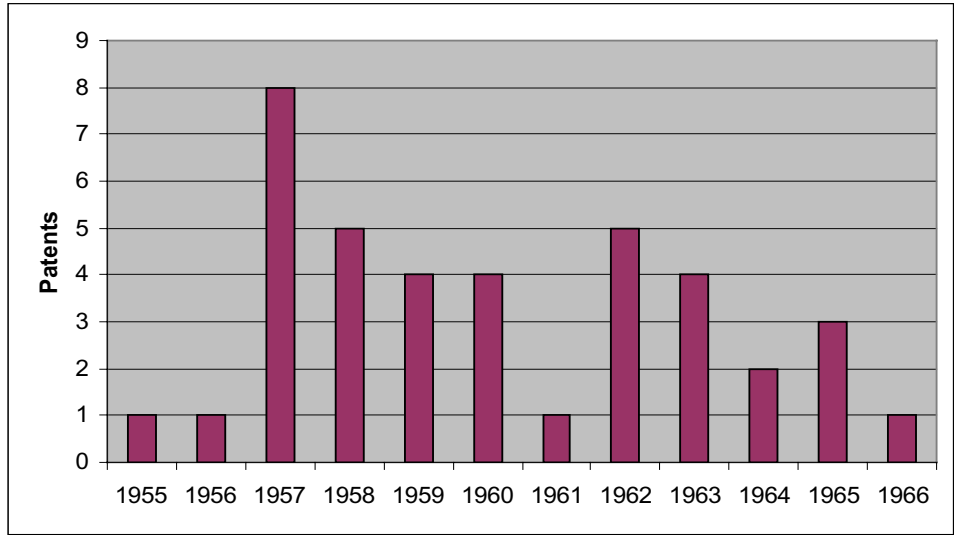

Source: Spanish Office of Patents and Marks. Historical Archive. Ministry of Industry, Tourism and Marks. Prepared by the author.

All these instruments were also employed to measure soil compaction and were used regularly in the courses on isotope applications to industry. Moreover, at the request of some industrialists for girders and columns, the JEN carried out some tests to detect the iron in the reinforced concrete 
with gammagraphy and nucleonic control. This enabled the detection of 4 $\mathrm{mm}$ of iron in concrete $20 \mathrm{~cm}^{\text {thick }}{ }^{45}$.

At the same time, the Chemistry Division of the JEN continued the policy of reducing imports of isotopes. Accordingly, an automated plant was built to produce Nitrogen 15 in order to prepare marked compounds such as ammonium chloride or ammonium nitrate ${ }^{46}$. A high activity Chromium 51 by means of irradiation of potassium chromate was obtained for use as a tracer to protect living organisms from contamination ${ }^{47}$.

To this list may be added other isotopes already in production -Carbon 14, Sulphur 35 and Iridium 192- and the ones to be prepared -Manganese 54, Iron 50 and Iodine $131^{48}$. These isotopes were produced in excess and exported with the help of the Commissariat de l'Energie Atomique ${ }^{49}$. The United States, Canada and France were the main importers ${ }^{50}$. Owing to this overproduction, Gregorio Lopez Bravo (minister of Industry) highlighted the need to use isotopes and proposed information campaigns during the closing ceremony of the I Symposium of isotope applications held in the JEN in $1967^{51}$. Henceforth, the phase of dreams became transformed into a phase of promotion of isotopes to absorb overproduction.

\section{The food industry}

As for the applications of isotopes in agriculture (as in the case of industrial applications) the phase of dreams in which isotopes were regarded as the solution to all the major problems of mankind, such as hunger, had come to an end in Spain. Thus, in 1955 there were already articles on the applications

45. Del Val Cob, M.; Plata Bedmar, A. Utilización de isótopos radiactivos en problemas de construcción. II. Medida de la densidad de tierras y localización y medida de armaduras de hierro en hormigón. Energía Nuclear. 1966; 40: 115-124.

46. Producción en la JEN de compuestos marcados con N-15. Energía Nuclear. 1967; 47: 246.

47. Novedades en la producción de isótopos radiactivos en la JEN. Energía Nuclear. 1966; 41: 265.

48. Domínguez, G.; Del Val Cob, M. Consumo y aplicaciones de los radioisótopos en España en 1965 y 1966. Papel de la Junta de Energía Nuclear. Energía Nuclear. 1967; 48: 389-401.

49. Producción y consumo de isótopos radiactivos en España en 1964. Energía Nuclear. 1965; 37: 377-389.

50. Noticiero. Energía Nuclear. 1968; 52: 117-133.

51. I Simposio sobre aplicaciones de los radioisótopos. Acto de clausura. Energía Nuclear. 1967; 48: 267-269. 
of isotopes to improve harvests and increase food production. There were even reports on the first radioactive eggs laid by hens fed with previously irradiated seaweed ${ }^{52}$. Moreover, references were made to the use of tracers to determine the metabolism of plants, the action of insecticides and the diseases of animals due to incorrect feed ${ }^{53}$. The possibility of subjecting seeds of different plant species to radioactive cobalt before sowing in order to obtain more disease resistant varieties was also considered ${ }^{54}$. Articles were published on experiments that used insecticides and fungicides marked with isotopes to better understand the life cycle of insects and fungi and to devise more effective ways to combat them ${ }^{55}$. In 1960 , there were reports on the irradiation of potatoes in the USA to eliminate shoots ${ }^{56}$, and on the cultivation of «Golden delicious» apples and peanuts with irradiated seeds ${ }^{57}$.

If these experiments were regarded as fantastic in Spain this was not the case in other countries given that these techniques had first been developed in 1954 when the Quartermaster Corps of the US Army had embarked on a program of food sterilisation with the aim of prolonging its shelf life. Subsequently, other countries such as England, Canada and France followed suit. From 1960 onwards this program was adopted by civil authorities, taking advantage of this military experience. In early 1962, there were 12 laboratories in Europe that were engaged in the irradiation of meat and 9 in that of fish. There were 20 labs engaged in irradiating fruit and vegetables and 10 in that of miscellaneous products. Moreover, there were 60 irradiation units and 100 researchers employed in this sector ${ }^{58}$.

\footnotetext{
52. La puesta de los primeros huevos radioactivos. Ibérica. 1955; 314 (22): 294.

53. Rocasolano, Cándido. La energía atómica en agricultura i ganaderia. El Cultivador Moderno. 1955; 38: 86.

54. Juscafresa, Baudilio. La energía atómica y la agricultura. El Cultivador Moderno. 1955; 38 (11): 407-408.

55. Rocasolano, Cándido. La energía atómica en agricultura. El Cultivador Moderno. 1955; 41 (1): 20-22.

56. Efectos de los radioisótopos en la conservación de las patatas. Ibérica. 1960; 421, vol. 31, 15 Mar: 213

57. Obtención de nuevas variedades de frutas por medio de la energía nuclear. Ibérica. 1955; 31: 168.

58. Del Val Cob, Manuel; Ortín Suñé, Nicasio. Conservación de alimentos por irradiación. I. Evolución y estado actual en el mundo. Energía Nuclear. 1965; 34: 95-111.
} 
In Spain, by contrast, activity in this field had not yet got under way. Nevertheless, the construction of the Naiad unit irradiation was once again to play a providential role. Since its inauguration, the JEN began to undertake studies on irradiation with the collaboration of the Institute of Agronomic Research.

There were three reactors in Spain in 1964: JEN-1, Argos and ARBI. However, it became necessary to have one unit available to carry out irradiation with gamma rays. The JEN adapted the basement of the Section of Isotopes to build this unit known as Naiad - the mythological nymph who lived in fountains, rivers and lakes.

Naiad took the form of a well filled with water at the bottom of which was the radioactive source of Cobalt 60 of 7.700 curies of activity. The source was placed in a circle in the middle of which was the sample to be irradiated. After its inauguration in December 1964 this unit was used for irradiating different kinds of materials such as food, wood and paint. It was also used to carry out research into solid state physics, chemistry of radiations and permeability changes of cells for research centres of the JEN or the CSIC such as the «Rocasolano» Institute of Physical Chemistry or the «Alonso Barba» Institute of Chemistry and also for the Service of Forest Plagues and Nuclear Applications of Barcelona ${ }^{59}$.

Naiad marked the beginning of the agricultural studies in the JEN. This research was conducted together with the Agricultural Research Institute (Instituto de Investigaciones Agronómicas). Subsequently, some tests were carried out on irradiation of potatoes, onions, strawberries, lemons, oranges and wheat. The first study (December 1965) concerned two native varieties of potatoes - Álava and Gineke. The test sought to determine the optimum dosage needed to prolong storage and delay sprouting. On this occasion the Section of Isotopes of the JEN collaborated with the Animal Physiology Laboratory of the Pharmacy Faculty of Granada University in an attempt to ascertain whether the irradiated potatoes were eatable and to determine the effects of the rays on nutrition. ${ }^{60}$ Four years later this

59. Fornas, E.; Del Val Cob, M.; De la Cruz, F. La unidad de irradiación «Nayade» de cobalto-60. Energía Nuclear. 1966; 43: 376-388.

60. Rivas, A.; García de Mateos, A.; Ortín Suñé, N.; Del Val Cob, M. Conservación de alimentos por irradiación. V. Estudio económico del mercado de patatas en España y posibilidades de su conservación por irradiación. Madrid: Junta de Energía Nuclear; 1967; García De Mateos A.; Rivas García, A.; Ortín Suñé, N.; Del Val Cob, M. Conservación de alimentos por irradiación. 
research began to have repercussions in the food industry. The Ministerio de Gobernación (Home Office) authorised the company Ansa-Radiaciones S.A. in Barcelona to use gamma rays to commercialise irradiated potatoes for human consumption. This was the first time isotopes were authorised in Spain for food conservation ${ }^{61}$. The research was accompanied by legislation and a ministerial decree in 1966 to promote and regulate installations for food preservation by irradiation ${ }^{62}$.

There is no evidence to support the transfer of technology between the JEN and the company of potatoes but it seems very likely that the research of the JEN had implications for the creation of the company of Barcelona, for the authorisation issued to undertake this kind of nuclear activity and for the subsequent legislation.

In addition to the work of the Naiad unit, this research received a fresh impetus in 1965 when the JEN participated in the Seibersdorf Project. This international programme was sponsored by the Atomic Energy Commission of Austria, the European Organisation for Cooperation and Development (OECD) and the International Organisation of Atomic Energy (OIEA), and undertook the study of food preservation by irradiation. One of the first research subjects was to analyse the aroma of fruit juice. The JEN was responsible for apple and grape juice.

The Naiad unit examined irradiated samples of different varieties of Austrian grapes and apples and only two types of Spanish apple. This grape juice gave off a nauseating smell with the result that this method of conservation was invalidated. As for the apple juice, there was no substantial change in the aroma despite a strong smell of stale juice. It was concluded that irradiation modified the aromatic compounds by degrading the volatile compounds ${ }^{63}$.

This research paved the way for further studies. Thus in 1968 the Direction of Chemistry and Isotopes signed two contracts with the OIEA

VII. Investigaciones realizadas con dos variedades (Alava y Gineke) de patatas españolas. Madrid: Junta de Energía Nuclear; 1967.

61. Noticiero. Energía Nuclear. 1969; 62: 620.

62. Order of the Minister of Industry, September 8, 1966 and Decree October 61966 (BOE 31-101966). Ortin Suñé, N. Estado actual, posibilidades futuras e impacto económico potencial de la conservación de alimentos por irradiación a escala comercial. Energía Nuclear. 1967; 48: 379-387.

63. Barrera, R., Gascó, L. De la Cruz, F. Alteraciones de aroma en zumos de frutas irradiadas. Energía Nuclear. 1968; 52:117-133. 
to compare fish microflora with the residual flora following irradiation and to determine the volatile compounds (smell) of irradiated fish. Hake was selected given that it was the most common fish in the local diet ${ }^{64}$. Subsequently, in late 1969 the JEN agreed to construct a Research Centre of Irradiation equipped with laboratories for the analysis of irradiated foods ${ }^{65}$, Spain signed an international agreement on irradiated foods and Ricardo Fernández Cellini was appointed vice-president of the council to regulate this subject ${ }^{66}$.

\section{The era of tracers}

The I Symposium of applications of isotopes held in Madrid in 1967 also established the lines of research on the applications of tracers in hydrology, agriculture and industry ${ }^{67}$.

Tracers had a long application in the field of medicine and radiobiology even in Spain. In the words of Maria Jesús Santesmases: «The use of iodine-131 for experimental endocrinology in research on endemic goitre was introduced by Gabriela Morreale and Francisco Escobar from Granada in the late 1950s. From the mid 1960s onwards Margarita Salas and Eladio Viñuela began using Phosphorus 32 and Carbon 14 in their laboratory of molecular biology in Madrid» ${ }^{68}$. But the applications of tracers in industry and agriculture continued to lag behind.

The technique of tracers consists in using the isotope not as a radioactive source but in a mixture to subsequently detect radioactivity in another phase or place.

In hydrology, tracers have been used to measure the flow of rivers in Spain since 1964 following the agreement between the JEN and the OIEA.

64. De la Sierra Serrano, Daniel. Conservación de alimentos por irradiación. Irradiación de productos de la pesca. Energía Nuclear. 1970; 68: 483-493; Barrera, R.; Gascó, L. Compuestos radiolíticos volátiles en pescado irradiado. Energía Nuclear. 1971; 69: 21-33.

65. Fernández, J; Ortín, N. Métodos nucleares para reducir la pérdida de los alimentos. Energía Nuclear. 1972; 76: 191-195.

66. Noticiero. Proyecto internacional de irradiación de alimentos. Energía Nuclear. 1971; 69: 6869.

67. Fernández Cellini, R. I Simposio sobre aplicaciones de los radioisótopos. Energía Nuclear. 1967; 48: $261-266$

68. Santesmases, n. 1, p. 775. 
Methods and instruments were first developed and then Bromine 32 was used to determine the flow of the river Tagus ${ }^{69}$. This application allowed the JEN to be integrated into the Hydrology Institute and to participate in projects concerning the detection of leaks in urban water pipes or in dams $^{70}$.

The food industry exploited the use of tracers to improve crops and to analyze the effects of pesticides. Thus the JEN experimented with Phosphorus 32 to determine the quantity absorbed by the soil. Also, in 1965, the evolution of Iron and Manganese in fertilising two kinds of soils (calcareous or non calcareous), using Manganese 54 and Iron 59 as tracers, was determined ${ }^{71}$.

In the early 1960s the use of pesticides was so widespread that it posed a risk of contamination. The OIEA and the FAO entrusted one group of experts to study some alternatives. These experts recommended research into marked pesticides to determine their evolution and reduce their effects ${ }^{72}$. To this end, the JEN prepared and sold more than eighteen kinds of marked pesticides ${ }^{73}$ and undertook research into herbicides.

Marked herbicides could be used as tracers. This would facilitate the study of herbicide residues and their effect on the following harvest. One of these studies - which became a model for subsequent studies - was carried out by the JEN on one herbicide common in wheat fields: $(2,4$ dichlorphenoxy) acetic acid known as 2,4-D marked with Carbon 14. It was agreed that in a normal dosage $(1 \mathrm{~kg} / \mathrm{Ha})$ the herbicide that remained for one year was insignificant because of microbial degradation and the effect of rain ${ }^{74}$.

The application of isotopes as tracers in industry involved the JEN in a study for the SEAT automobile company (Sociedad Española de Automóviles de Turismo) in collaboration with students from the Industrial Engineering

\footnotetext{
69. Noticiero. Energía Nuclear. 1968; 52: 117-133.

70. Domínguez, n. 48, p. 390.

71. Costa Yagüe, F. Empleo de trazadores radioactivos en investigación agrícola. Energía Nuclear. 1965; 48: 363-377.

72. RADIOISÓTOPOS para la protección del peligro de los pesticidas. Energía Nuclear. 1965; 36: 322-323.

73. PRODUCCIÓN de insecticidas marcados con radioisótopos en la Junta de Energía Nuclear. Energía Nuclear. 1966; 43: 443.

74. Fernández González, J.; Ortín Suné, N. Empleo de trazadores radioactivos en el estudio de los residuos de herbicidas en el suelo. I. Aplicación al 2,4-D. Energía Nuclear. 1969; 51: 325-334.
} 
School from Madrid. This study concerned the wear and tear of the chrome piston rings of the engine of the SEAT 1500 CA automobile using Iron 59 and Chromium 51 as tracers.

To this end, it was necessary to construct a test bench in the laboratory of the JEN. The test consisted of four stages: 1 ) the rings inside the nuclear reactor were irradiated; 2) the rings were assembled in the motor; 3 ) the motor was tested under different experimental conditions; and 4) the radioactivity of the metallic particles in the lubrication oil was measured to determine the degree of wear and tear of the rings ${ }^{75}$.

All the above activities of the JEN concerning tracers were developed between 1964 and 1971, between the third and fourth Geneva conferences. Subsequently, the JEN collaborated in evaluating turbines at a hydroelectric power station, in determining the movement of marine sediments at Orzan in Galicia, and in detecting leaks in a heat exchanger at an oil refinery ${ }^{76}$.

Everything seems to indicate that the research and application carried out in the JEN closely followed the research lines of the most advanced countries. Thus, the originality of the Spanish applications was considerably reduced and was limited to small improvements in the usual methods of application.

\section{Exempted products}

Ten years after Roentgen discovered X rays, the first German Radiological Congress (1905) highlighted the need for regulation. It was recommended that the use of radiation be controlled by legislation to reduce the number of accidents, which at that time was high. In the following years, some professional associations started to elaborate rules and recommendations on safety. But it was not until 1928 that some guide lines on radiation were drawn up by the Prospection International Commission (known as International Commission of Radiological Protection, after 1950).

75. Del Val Cob, M.; Chul Yoo, B.; Fuentes Figuera de Vargas, J. Estudio del desgaste de segmentos de motor Seat 1500 CA mediante trazadores radiactivos. Madrid: Junta de Energía Nuclear; 1971.

76. Fuentes, J. Aplicaciones industriales para el estudio, la investigación y la explotación de recursos de los radioisótopos. Energía Nuclear. 1972; 76: 177-183. 
Legislation on nuclear facilities was strict given their hazardous nature. However, the use of radioactive sources not located in a nuclear installation was regulated differently in each country. Regulations were drawn up in accordance with the needs.

Legislation on ionizing radiations in Spain goes back to 1964 with the law of 25/1964 on nuclear energy. This law, which laid down some regulations for nuclear and radioactive facilities, was approved in 1972 and continued to be operative until 1980, when a new decree was issued on activities in the nuclear combustible cycle. Moreover, a law setting up the Nuclear Security Council was enacted as a result of the National Energy Plan. The Nuclear Security Council in 1982 drew up regulations on protection against ionizing radiation. These laws and regulations were the only legislation in nuclear matters and on radioactive protection in Spain.

The law of 1964 on nuclear energy addressed liability in the event of a nuclear accident, risk cover, compensation claims and compatibility with international agreements. In accordance with this law, a radioactive installation was defined as a radioactive source, i.e. the devices that produced ionizing radiation including premises, laboratories, factories and facilities that manipulated and stored radioactive materials. However, the installations whose radioactive source had an activity lower than natural radiation were assumed not to pose a hazard and were exempted from this law. Fluorescent watches were one example of the products that were exempted.

As regards radioactive sources of low intensity, the fact that these were considered to pose no risk to health can be traced to the origins of the discovery of radioactivity. At that time, ignorance about radioactive risk resulted in these sources being used without protection. This was the situation in 1920.

As a result of the studies of Marie Curie in the early years of the XX Century, it was well known that the combination zinc sulphur and Radium 226 produced fluorescence because of the emission of alpha rays. This discovery was exploited by the watch making industry to produce fluorescent dials not only in watches but also in other instruments for measuring. This kind of luminous paint was initially employed without safety precautions in the USA. Consequently, female workers, unaware of the risks, tapered the paint brush with their lips, which resulted in fatalities due to Radium. 
The uncontrolled diffusion of watches or other devices such as smoke detectors, constituted a problem in the mid sixties. In 1965 the OIEA, the ENEA (European Nuclear Energy Agency) and the WHO (World Health Organisation) conducted a survey in 40 countries in order to prepare a guide to describe the type and number of the exempted applications. The fluorescent dials and smoke detectors were among the most popular devices in the world ${ }^{77}$.

The JEN undertook some research into the risk posed by fluorescent dials, which were very popular in Spain. Accordingly, the Division of Medicine and Safety contacted the manufacturers of watches and instruments to obtain samples to study. This research concluded that the dials of different instruments, such as thermometers or manometers, were painted with Radium 226. This isotope was outlawed in other countries in the case of pocket watches and was replaced by Tritium (H-3) or Promethium (Pm147), which was less hazardous than Radium. Some samples revealed contamination not only in the watch but also in the wrapping paper due to the poor adhesion of radioactive paint ${ }^{78}$.

Despite this, these products continued to be exempt from the new regulation established in $1967^{79}$. This was not the case in countries such as Switzerland, an important producer of watches, where special legislation was enacted. Nevertheless, Spanish law provided compensation for affected individuals. Two types of claims were recognized by the law: immediate claims indemnified by the persons who were directly responsible, and subsequent claims which were compensated by the State ${ }^{80}$.

Accordingly, with the law of 1980, the Nuclear Security Council established a specific regulation for the radioactive facilities of activity below $0.1,1,10$ and 100 micro curiums in line with international regulations.

77. Ramos Rodríguez, Eduardo. Control y vigilancia de productos industriales «exentos» que contienen núclidos radiactivos. Comentarios a una guía de la OCDE, OIEA, OMS. Energía Nuclear. 1970; 67: 419-425.

78. Velilla Manteca, Antonio. Relojes de esferas luminiscentes. Energía Nuclear. 1968; 51: 41-53.

79. Regulation on coverage of nuclear risks (Reglamento sobre cobertura de riesgos nucleares). Decree 2177/ 67 July 22, 1967 (B.O.E. September, 18), modified by Decree 742/68 March 28 (B.O.E. April, 20).

80. De los Santos Lasurtegui, Alfonso; Corretjer Palomo, Luz. Aspectos jurídicos del uso de fuentes de radiaciones ionizantes. Energía Nuclear. 1969; 61: 431-440. 


\section{Culmination of the phase}

The decade of the 1970s bore the first fruit of the work undertaken by the JEN in the preceding years. The most important development to emerge was a private company with a unit of irradiation for sterilisation of medical and surgical products. This unit, which had an activity of 330,000 Curies of Cobalt 60 and was able to treat $5,000 \mathrm{~m}^{3} /$ year of material, was termed Cesar. This is a clear example of the transfer of technology from a public institution to a private company. The JEN constructed this sterilisation unit and sold it to a private company.

The owner was Josep M. Aragó Mitjans from the Aragó Laboratory. The Cesar unit was located at Franqueses del Vallés near Granollers (Barcelona). In the 1980s this company became a limited company and was divided into two companies: Aragogamma S.A. the current irradiation plant and Laboratori Aragó S.A. ${ }^{81}$.

In addition to medical applications, this company also collaborated with pharmaceutical, cosmetics and food companies. Irradiation is completely automated with a product that is packed in standard boxes of 30 $\mathrm{cm}$ in length and a maximum weight of $7.5 \mathrm{~kg}$. In its publicity brochure, Aragogamma boasts that it is the only industrial plant of irradiation in Spain.

The instruments of industrial control, which underwent an increase in use in the 1960s continued to increase, reaching equilibrium in the early 1990 s with a replacement rate of a 100 radioactive sources per year ${ }^{82}$. The JEN carried out some studies to eradicate the fruit fly (Ceratitis capitata). The method involved the sterilisation of male flies in Tenerife and Murcia ${ }^{83}$. In the sector of irradiated food, the JEN performed tests on irradiated fish flour for pigs and on chicken feed in accordance with the OIEA and demonstrated that there was no risk ${ }^{84}$. The Naiad unit,

81. Fuentes, n. 76, p. 180.

82. Caro, R. et al. Historia Nuclear de España, Madrid: Sociedad Nuclear Española; 1995, p. 306.

83. Fernández, J.; Ortín, N. Utilización de métodos nucleares para aumentar la producción de alimentos de origen vegetal. Energía Nuclear. 1972; 76: 185-189.

84. De la Sierra Serrano, D.; Casas Medina, F. Pruebas de comestibilidad de alimentos irradiados. I. A. Prueba inicial en aves de comestibilidad de harina de pescado irradiada. Energía Nuclear. 1974; 87: 29-39. 
in the 1970s, conducted studies in an effort to improve the mechanical resistance of poplar wood for industrial applications ${ }^{85}$.

\section{Conclusion}

This overall view of the application of isotopes in industry falls into two phases: an initial phase, i.e. dreams whose origin can be traced to the end of WWII, and a later phase, i.e. promotion of needs. The initial phase, which was accompanied by considerable enthusiasm, concerns the presentation of the peaceful applications of nuclear energy, i.e. a solution to the major problems afflicting mankind. This perception was not random but sprang from the desire of the victorious nations to change the negative image created by the atom bomb. This perception was brought about by the diffusion of articles extolling the virtues of isotopes in technical journals. In the specific case of Spain we saw how diverse publications highlighted the advantages that could be obtained if isotopes were applied in industry and agriculture. All this had the effect of enlightening not only the scientist but also the general public about the beneficial uses of nuclear energy.

As a result of the American policy known as the Atoms for Peace Programme, USA and Spain reached an agreement on the peaceful applications of nuclear energy, which paved the way for the use of isotopes. With foreign aid it was possible to build an experimental reactor, which became the main source of isotopes in Spain. As soon as the reactor was completed, an infrastructure was established to supervise and control the new techniques: the Section of Isotopes. As regards training, the School of Industrial Engineering of Barcelona implemented isotope courses for industrial applications.

Subsequently, the dreams became a reality and the JEN carried out research, prepared isotopes and participated in international meetings. The institutional impetus was so great that it exceeded the needs of the country.

The phase of the promotion of needs came into being at this time. We saw how the research centres and teaching institutions participated in the

85. Esparraguera, I. Radiopolimerización de monómeros en madera. Energía Nuclear. 1974; 89: 157-165. 
training of the uses of isotopes in industry and agriculture. The construction of nuclear reactors for research paved the way for the implementation of production processes of these isotopes in the JEN, which distributed them to users. In some cases, more isotopes than necessary were produced. Although overproduction of some isotopes was absorbed by exportation and by a policy of promoting local needs, the demand for imported isotopes never ceased. Despite the initial reservations of the industrialists, the phase of dreams was transformed into a phase that fostered economic needs in accordance with the economic development of the 1960s.

The international climate of isotope applications in industry favoured their implementation in Spain. In this regard gammagraphy was consolidated in 1964 and control instruments were implemented in industry. Subsequently, the Spanish food industry introduced conservation by irradiation with the creation of the Naiad unit. Between 1964 and 1971 tracers were introduced and applied to measure river flow, study the effect of pesticides in agriculture, and to analyze the wear and tear of automobile motors. This process came to fruition in the early 1970s when the first results became tangible.

The most distinctive feature of technological transfer was, probably, the project and construction of an irradiation unit by the JEN for a private company to sterilise surgical products.

The implementation of the uses of isotopes in industry soon became a reality and some private companies incorporated instruments to measure thicknesses and levels, densitometry, sterilisation and non destructive assays among other applications.

The JEN played a central role in training users and in the production and distribution of the isotopes. These activities were facilitated by the availability of research reactors in the National Centre of Nuclear Energy. In addition to production and training, the JEN encouraged the use and the diffusion of these applications in private companies. 